\title{
E-TRANSACTION IN DIGITAL ERA
}

\author{
T Rohmawati \\ Departemen Ilmu Pemerintahan, Universitas Komputer Indonesia, Indonesia \\ Email: timkonferensi4@gmail.com \\ H Zulkipli \\ Departemen Akuntansi, Universitas Komputer Indonesia, Indonesia \\ Email: timkonferensi4@gmail.com
}

\begin{abstract}
This study aims to analyze student habits in information technology in conducting transactions either in cash or by using e-money. Questionnaire was a method used in this study by distributing selected questionnaires only to students. Analysis of the results showed that the students preferred to use e-money for transactions because it was more effective and more efficient than paying in cash. It could be also because it was influenced by their shopping habits through social media and the globalization era. On the other hand, they needed cash and relatively bigger wallet for cash payments. Consequently, e- money was preferred by students compared to cash payments.
\end{abstract}

\section{Keywords: E-Transaction, Digital, E-Money, Social Media}

Received: 1 April 2021 ;

Accepted: 10 November 2021 ;

Publish: December 2021

\section{How to Cite:}

Rohmawati, T., Zulkipli, H. (2021). E-Transaction In Digital Era. Journal of Business and Behavioural Entrepreneurship, 5(2), 51-.56. https://doi.org/10.21009/ JOBBE.005.2.07 


\section{INTRODUCTION}

Information technology is generally a very common thing these days. Its development resulted in the community having to adapt to it; for example, transaction in cash can now be replaced by electronic money. Electronic money or e-money is a technology-based financial product where the users numbers are increasing in each day regardless of the users age. Financial technology is a developing technology in finance, and it is monitored by people. In this development, there are two types of payment systems, namely cash and electronic money. Each has very different characteristics and the users of the system will certainly be different. E-money can be used only on modern outlets, while the cash system is still maintained by outlets that use the outdated system. The development of technology in finance makes people who are in the middle to lower classes sense the urgency to try this technology so that they are not getting left behind (Chuen, 2017). The strong impact that digitalization currently has is affecting the financial industry services. All financial products at this time are mostly based on information technology.

Furthermore, finance is currently and entirely carried out without physical interaction. Fintech is an innovation in the financial services industry that utilizes the use of technology (Puschmann, 2017). Meanwhile, research conducted in Zimbabwe regarding e-money and cash payment showed that the use of e-money is inacceptable to every individual yet. This is because most people there prefer to use the cash payment system compared to e-money. The survey showed several reasons to not use electronic money because of fear from the community itself, the lack of public confidence in the banks, and the lack of information about e-money (Sakarombe \& Marabada, 2017). Emoney is the latest form of cash in the form of data (Iwamura et al., 2019). Many factors cause a person choose e-money compared to cash, namely comfort, security, functions, costs used, and financial transparency with the bank (Sasai et al., 2018). Every debt will be settled immediately. Therefore, there is no risk from various parties. Transactions are very final. People are directly involved in the transactions even if they do not trust each other.

However, the disadvantage of cash payment is the people involved must be physically present and it is impossible to that online. This is where electronic money becomes an opportunity for new market to facilitate traders who use online trading (Rogoff, 2017). The development of information technology in the financial sector will not stop here. There are many more products that will be generated by financial technology besides the payment system (Lee \& Shin, 2018). At this time, small and medium businesses mainly make transactions on social media so that the payment system will continue to develop. If the entrepreneur does his business on digital media, it will not be separated from the three elements of digital methods, digital platforms, and digital infrastructure which includes payment systems that are made digitally or electronically using internet connection (Nambisan, 2017).

E-money balance is calculated based on the amount of money on the card, however the balance is not categorized as savings bank. After the concept of e-money itself, the user must first deposit the money so that the money in the card increases (Liébana-Cabanillas et al., 2018). To prevent any digital issue related to e-money, the Indonesian government has coordinated with the Indonesian Finance Ministry and banks to protect their customers who use e-money. Entrepreneurs expect the effectiveness from e-money will cut the time needed for finishing a payment. Moreover, the efficiency it has is expected to provide security, assurance of free from counterfeit money, and easiness in receiving finished payments (Sullivan \& Burger, 2017). 
This research has the following objectives: to compare preferred payment systems, the effectiveness and efficiency of them, and the reasons for choosing both methods. Questionnaire was a method used in this study by distributing selected questionnaires only to students. This research has the following objectives: to compare preferred payment systems, the effectiveness and efficiency of them, and the reasons for choosing both methods. Questionnaire was a method used in this study by distributing selected questionnaires only to students.

\section{RESEARCH METHODS}

This research method used was a questionnaire method by distributing selected questionnaires through Google Forms to Accounting students of Universitas Komputer Indonesia who use social media for conducting transactions in cash and e-money. The distribution of questionnaires was conducted on October 8, 2019 to October 14, 2019. The aim was to find out transaction payment methods selected by students in conducting transactions. Young adults mostly choose to use e-money because of its effectiveness and efficiency compared to cash. By comparing these two transaction methods, entrepreneurs must prepare e-money for their transaction payment.

\section{RESULTS AND DISCUSSIONS}

Respondents' responses related to the relationship with the e-money method showed the result that if they would make a payment transaction, 14 of 24 respondents chose to make transactions using the e-money method and the rest chose cash transactions. The reason for choosing e-money was because it is accessible, comfortable, and safe. In addition, e-money platforms regularly offer discounts to the user (Lee \& Shin, 2018). In contrast, the reason for choosing cash was because several outlets do not accept e-money transaction. Therefore, according to me, cash is generally accepted in community while e-money is accepted in more specific outlets. However, because of the rapid development of technology and information, people who previously use cash payment now use e-money. Market must slowly keep up with current developments and the use of e-money is inevitable.

The intensity of the respondents in using e-money is shown in Figure 1. It shows that $33.3 \%$ of respondents were frequently conducting transactions using e-money because of the easiness and low-risk payment compared to pay in cash. In addition, conducting e-money payments gave the users points to get discounts for future purchases (Nambisan, 2017). In addition, students started paying their tuition fees with autodebit system instead of cash because the campus had been working with the bank to facilitate their students pay tuition fees much easier. Tax payments, zakat payments, toll payments and advertising payments are now already using e-money through digital media. It is not surprising that e-money transaction payment in Indonesia has increased each year. Nevertheless, paying in cash was still the main option for small enterprises because they did not have the tools that support e-money transaction. Despite of the high use of e-money, cash payments are still needed (Figure 1). 


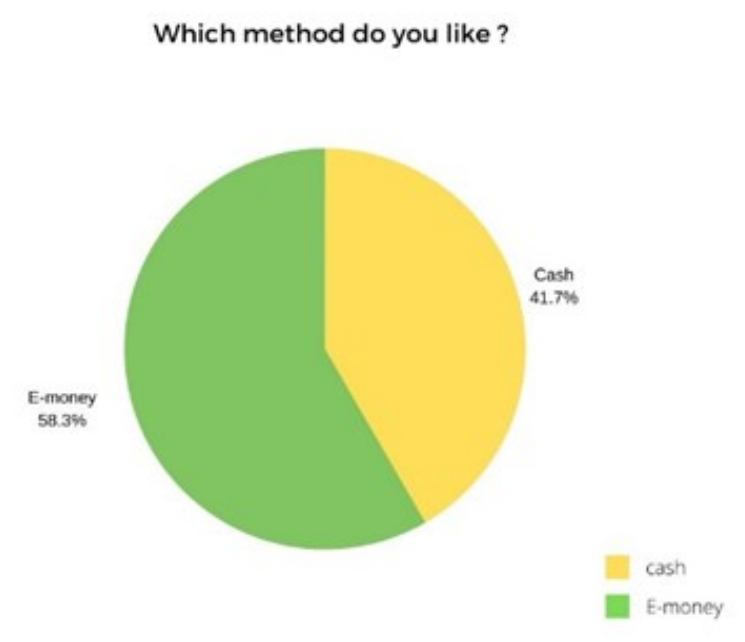

Figure 1. The intensity of the respondents in using the e-money method

Figure 2 shows the effectiveness of both methods and the result e-money was chosen as the most effective method. Using e-money enabled the users to carry less money and avoid the feeling of worry of losing it. When the e-money card was lost, users only lost the card and not the money.

The results of the questionnaire survey showed that e-money payment is more effective than the cash payments. It was driven by many factors including the current habit of students for choosing simple way. They could buy books online and pay them using e-money without having to go to the bookstore which cost them more time and money. However, cash is still used for certain payment where e-money transaction is not supported (Figure 2).

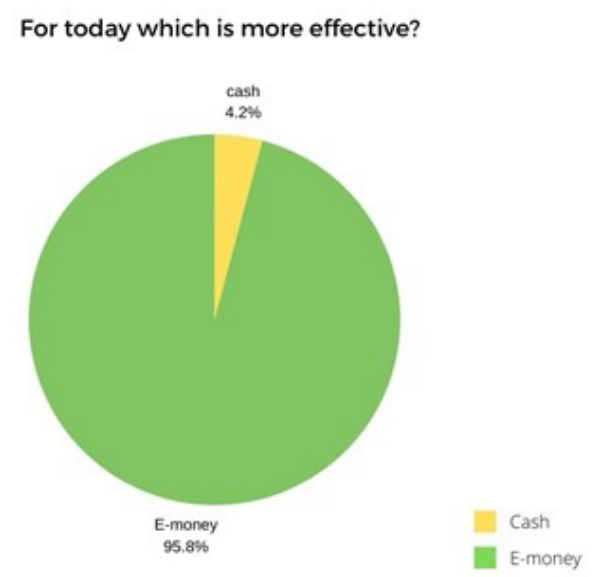

Figure 2. Respondent's responses to the effectiveness of both methods 
Figure 3 shows the reasons for choosing e-money over cash. It showed that emoney transactions were easier and quick. Meanwhile, some preferred cash because they did not have to deposit balance on the e-money platforms.

It can be said that e-money platforms are successful in promoting e-money because they could get the students' attention to use it. In order to get the attention, emoney platforms usually offer discount, special price, or cashback in large amount. On the other hand, those promotions did not happen regularly for cash payment (Figure 3).

E-money lots of cashback and discounts
The reason for choosing cash is because there is no need to complicated top your balance
The reason for e-money is that besides being more effective it also often gets cashback
e-money is more practical, no need to withdraw money to the bank first.
Cash, because more often use cash do not need to fill the balance first
E-money is more effective and not complicated
Because it is more efficient than cash
More simple
E-money is more effective and not complicated for modern times like today

Figure 3. The reasons of the respondents for choosing each method

\section{CONCLUSION}

E-money as a product of the development of information technology is able to provide solutions that have been an obstacle for every individual. Using e-money makes it easy for everyone to make transactions online and it can work properly. However, the cash payments cannot be eliminated because it is still needed for certain parties such as traders or entrepreneurs who make offline transaction and have not gotten the technology for e-money transactions. Thus, e-money payment and cash payment have its own advantages and disadvantages in the era of globalization. Nevertheless, emoney is seen to be the most effective and efficiency payment for students.

\section{REFERENCES}

Chuen, D. L. K. (2017). Invited Editorial Comment: FinTech and Alternative Investment. The Journal of Alternative Investments, 20(3), 6-15.

Iwamura, M., Kitamura, Y., Matsumoto, T., \& Saito, K. (2019). Can we stabilize the price of a cryptocurrency?: Understanding the design of Bitcoin and its potential to compete with Central Bank money. Hitotsubashi Journal of Economics, 41-60.

Lee, I., \& Shin, Y. J. (2018). Fintech: Ecosystem, business models, investment decisions, and challenges. Business horizons, 61(1), 35-46.

Liébana-Cabanillas, F., Muñoz-Leiva, F., \& Sánchez-Fernández, J. (2018). A global approach to the analysis of user behavior in mobile payment systems in the new electronic environment. Service Business, 12(1), 25-64.

Nambisan, S. (2017). Digital entrepreneurship: Toward a digital technology perspective of entrepreneurship. Entrepreneurship theory and practice, 41(6), 10291055 . 
Puschmann, T. (2017). Fintech. Business \& Information Systems Engineering, 59(1), 69-76.

Rogoff, K. (2017). Dealing with monetary paralysis at the zero bound. Journal of Economic Perspectives, 31(3), 47-66.

Sakarombe, U., \& Marabada, N. D. (2017). Electronic Money or Cash? In Face of Liquidity Crisis in Zimbabwe. International Journal of Academic Research in Business and Social Sciences, 7(11), 2222-6990.

Sasai, K., Tsujimoto, M., \& Higa, K. (2018, December). Key factors analysis of user's choice on electronic money services. In ISPIM Innovation Symposium (pp. 115). The International Society for Professional Innovation Management (ISPIM).

Sullivan, C., \& Burger, E. (2017). E-residency and blockchain. computer law \& security review, 33(4), 470-481. 